\title{
Design of Medical Biochemistry Undergraduate Laboratory Based Curriculum to Address Unmet Needs
}

\author{
Dandekar, S.P. ${ }^{1}$, Maksane, S.N. ${ }^{2}$, Mckinley, D.W. ${ }^{3}$
}

\begin{abstract}
Background and objectives: Review of the undergraduate medical curriculum in India is not done regularly. Strengths and weaknesses need to be identified in order to develop strategies to improve the curriculum. Objective was to critically appraise, modify and implement biochemistry laboratory based curriculum for undergraduates as an endeavour for critical introspection and to set a platform for change.
\end{abstract}

Methods: A self-administered questionnaire for faculty and interviews for students were used to identify needs which would help to create an educational environment conducive to change and innovation. The existing undergraduate biochemistry laboratory curriculum was analysed using Kern's framework, triangulating the qualitative and quantitative data, to develop a modified curriculum. As a pilot study, a checklist was made for one laboratory unit and the faculty was trained to use it. Kirkpatrick's model was used for evaluation of training.

Results: The major strengths and weaknesses of the curriculum were identified. Accordingly, the objectives, teaching - learning methods and assessment strategies were aligned. For the first time, measures for honing and assessing interpretative skills of students were incorporated. The results showed that three levels of Kirkpatrick's evaluation model were achieved for the training of the checklist. Paired ' $t$ ' test was used to check the differences in marks of students before and after applying the checklist of marks allotment. The mean score of the marks of one laboratory experiment unit (urine report) after applying checklist pattern $(M=9.18)$ was compared with the mean score of the marks without applying checklist pattern $(\mathrm{M}=10.12)$.

Conclusions: Evaluation of curriculum provided a snapshot of the strengths and weaknesses of current biochemistry practical curriculum and also guided improvements particularly with regards to inclusion of more clinically relevant curriculum with group based learning. The data derived from this study will help to make suggestions to the decision making bodies i.e. Medical Universities (both national \& state based) in India.

Keywords: curriculum design development and implementation, laboratory exercises

\section{Background}

A curriculum is a planned educational experience that encompasses behavioural instructional methods and the actual experience of the learners (Green, 2001).

\footnotetext{
1 \& 2 Department of Biochemistry, Seth G. S. Medical College, Mumbai, Maharashtra, India.

${ }^{3}$ Research and Data Resources Department, Foundation for Advancement of International Medical Education and Research (FAIMER), Philadelphia, Pennsylvania, USA.

Corresponding Author

Sucheta P. Dandekar, Department of Biochemistry, Seth G.S. Medical College and K.E.M. Hospital, Mumbai, Maharashtra, India.
}

E mail: sucheta.dandekar@gmail.com
The main intention of curriculum design is to foster goals, the academic development of students (Rethy \& Khoo, 2001). The curriculum is not a static system but in fact is a dynamic, interactive process, whereby changes of one step will affect and require adjustments of other steps (Brodsky \& Newman, 2011). It is a cycle which involves development through needs assessment, design and implementation phase (Peyton, 1998). Ideally the medical curriculum should empower medical students with a broad base of knowledge and practical skills that help them to become good clinicians. As the physicians requirement for knowledge and skills evolve, need for new curriculum is often felt to incorporate new knowledge and competencies (Epstein \& Hundert, 2002). 
Hence, there is a need for medical curriculum to be evaluated, corrected and sent through repeated levels of changes.

The knowledge of biochemistry is important for the diagnosis and management of various illnesses. Biochemistry is a basic science subject which is taught in the first phase of the undergraduate medical curriculum in most countries. An improvement in the teaching learning process can be planned by pilot implementations and by improvements in the curriculum (D'Souza et al., 2013).

Clinical Biochemistry Faculty has often debated that the contents, methods of teaching, and curriculum organization of training in clinical biochemistry in India needs to be modified (Mishra, 2000). Opinions have emerged through informal discussions with interns and final year medical students that the current undergraduate clinical biochemistry laboratory curriculum in Indian Medical Schools is not aligned to the modern trends in clinical biochemistry and laboratory medicine and does not reflect the actual content of the rapidly evolving discipline. Besides, at national level conferences formal meetings with senior biochemistry faculty members for curriculum discussion have also yielded concern for a revision in the undergraduate laboratory curriculum.

As an initial step, a formal needs assessment was conducted by collecting Clinical Biochemistry Faculty (from Medical Colleges of Maharashtra, India) views using a questionnaire as an endeavour for critical introspection. It endorsed that the on-going clinical biochemistry undergraduate practical curriculum implemented in the institute was not in alignment with learning outcomes and that it did not encourage active learning along with critical thinking and problem solving skills. There were a number of qualitative experiments that were rated as 'irrelevant'. The results of the curriculum evaluation suggest a need for restructuring of laboratory based biochemistry curriculum and introduction of a modified curriculum with more clinical relevance.

Through this survey, it was observed that outdated practical curriculum is a very serious issue affecting clinical biochemistry undergraduate education not only in Maharashtra but in all Indian medical schools (Dandekar et al., 2012). Also, students' perceptions about the laboratory based curriculum, different topics within the subject and their suggestions have not been reported in the recent times. Therefore, a need to evaluate and restructure the curriculum towards the newer trends in biochemistry and laboratory medicine was felt.

The aim of this study was to critically appraise the clinical biochemistry laboratory based curriculum by seeking student's perception, find out its strengths and weaknesses in order to lend more credibility for modification and to set a platform for implementation of improved curriculum by decision making bodies.

\section{Methods}

This study was aimed to analyse and modify the present biochemistry laboratory based curriculum at medical colleges of Maharashtra. Institutional academic ethics committee approval was sought and the same was gained. This study design was guided by three steps-1) Critical appraisal of current laboratory based biochemistry curriculum and identification of areas of modifications 2) Development of new curriculum and 3) Implementation.

A concurrent mixed method strategy was used in which quantitative and qualitative data were converged in order to interpret the overall results (Creswell, 2013).

\section{A) Appraisal}

For systematic appraisal of the biochemistry undergraduate practical curriculum, the authors sought faculty view through a questionnaire, examined the course document, and conducted interviews with students. Changes required in the present curriculum (additions and deletions) were sought, individual assessment evaluation was done and views about the new assessment pattern and marks distribution pattern (evaluation tool) for a particular experiment's evaluation were obtained (Dandekar et al., 2012). The details of this curriculum are available on the university website (MUHS curricula I).

The present study reports the following- 1) Analysis of current curriculum according to Kern's model of curriculum evaluation framework (Kern et al., 2010), and 2) Student's perception about current curriculum.

Perceptions of students about the current curriculum were sought by Senior Biochemistry Faculty of Institution. For this purpose, semistructured interviews were conducted to identify student's needs which would help create an educational environment conductive to change 
and innovation. Fifty interns and postgraduate students were included in the study as it was felt that they would be able to elicit the shortcomings of the curriculum while diagnosing and treating patients. Some of the questions asked to the students were: 1) What aspects of the current curriculum appear to be relevant to their role as a doctor? 2) What part of the curriculum needed to be changed? In these interviews students also discussed their educational and training experiences and made suggestions.

Interview data were analysed qualitatively. Open ended comments on the course evaluation survey for students were analysed through thematic coding with attention to generated themes. Thematic analysis is a qualitative data analysis strategy by which qualitative data are segmented, categorized, summarized, and reconstructed in a way that captures the important concepts within the data set (Braun \& Clarke, 2006).

Key points were extracted from student's comments and themes were generated. These themes were used for new curriculum designing (Table 3).

In the final step, triangulation of data from all the sources was done to prepare a modified curriculum. Triangulation is the process of "corroborating evidence from different individuals, types of data and methods of data to support the theme" (Berk, 2006).

\section{B) Modified Curriculum Development}

After formal teachers and learner's need assessment and curriculum evaluation through Kern's framework, a new modified curriculum was prepared which involved:

- Learning outcomes/objectives (knowledge, skills and attitudes)

- Content

- Teaching and learning methods

- Assessment methods

In this modified curriculum, objectives, teaching- learning methods and assessment strategies were aligned using John Biggs constructive alignment theory (Biggs, 2003).

C) Implementation and Monitoring of Evaluation Tool (Checklist)

A pilot implementation of one of the evaluation tools was conducted to gauge the effectiveness and validity of new ideas (McKimm, 2007). A checklist which was validated by the faculty for one laboratory unit was used for the practical assessment evaluation and the faculty was trained to use it (Figure 1).

\begin{tabular}{lc}
\hline \multicolumn{1}{c}{ Particulars (Urine Report) } & Marks allotted \\
\hline Physical characteristics (Writing + performing) & 1 \\
Specific gravity & 1 \\
Rest of the parameters such as colour, odour, etc & \\
Chemical constituents (writing + performing) & 1 \\
Proteins, Glucose & 1 \\
Blood & 1 \\
Bile salts and pigments & 1 \\
Ketone bodies & 1 \\
Clinical interpretation of the positive constituents & 2 \\
(generally we keep 2 positive constituents) & \\
Viva Voce & 5 \\
Report presentation format & 1 \\
Total & 15 \\
\hline
\end{tabular}

Figure 1: Checklist for Urine Report Experiment 
During the assessment for one of the units, (formative assessment), 6 teachers were requested to assess the urine experiment report by using a checklist pattern and also by using the conventional method. Answer sheets of 49 students were randomly selected for the process. For data analysis, SPSS software version 17 was used to calculate the $t-v a l u e, p-$ value and mean.

The implemented programme was monitored using Kirkpatrick's learning evaluation model was used to evaluate training given to faculty and effectiveness of checklist. Reaction was assessed by analysing feedback form filled by the faculty. The questions included in the feedback form were: 1) Have you used a checklist for practical before? 2) If yes-for what? 3) Did you find using this checklist convenient? 4) Were you able to finish assessing question more effectively because of the checklist? Learning was judged by comparing the student's scores with and without checklist and behaviour evaluation was done through observations (Kirkpatrick, 1998).

\section{Results} 1) Curriculum review as outlined by Kern's
Framework

The Kern's framework was used to review the learner and program characteristics, learning objectives, instructional strategies, feasibility and sustainability and effectiveness. After evaluation of curriculum, several strengths and weaknesses were found in the current practical curriculum (Table 1).

\section{Table 1: Strengths and weaknesses of the biochemistry practical curriculum}

\begin{tabular}{|c|c|c|c|c|}
\hline & Kern step & Data sources & Strengths & Weaknesses \\
\hline 1) & $\begin{array}{l}\text { Problem } \\
\text { identification and } \\
\text { general needs } \\
\text { assessment } \\
\text { conducted }\end{array}$ & $\begin{array}{l}\text { Syllabus content } \\
\text { and student- } \\
\text { faculty interview } \\
\text { Available on } \\
\text { MUHS website- } \\
\text { www.muhs.ac.in }\end{array}$ & & $\begin{array}{l}\text { - No relation of current curriculum to } \\
\text { public health and epidemiology. } \\
\text { - Not focused to improve knowledge } \\
\text { attitude and analytical skills needed } \\
\text { in modern practitioners. } \\
\text { - Clinical importance of the } \\
\text { biochemical tests is neglected. } \\
\text { - Lack of sound scientific base for } \\
\text { prescribing of biochemical tests as a } \\
\text { clinician. }\end{array}$ \\
\hline 2) & $\begin{array}{l}\text { Needs } \\
\text { assessments } \\
\text { with targeted } \\
\text { learners }\end{array}$ & $\begin{array}{l}\text { Syllabus, content, } \\
\text { student-faculty } \\
\text { interview and } \\
\text { Institutional } \\
\text { magazines- } \\
\text { Shidori and } \\
\text { Drishti. }\end{array}$ & 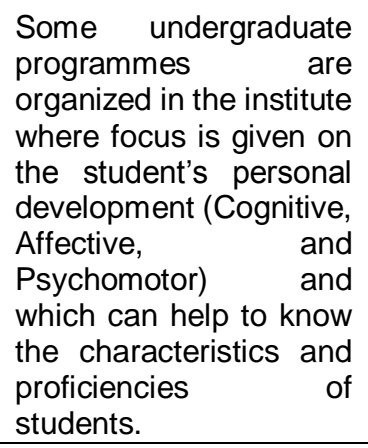 & $\begin{array}{l}\text { - No evidence that these programmes } \\
\text { are being used in targeted needs } \\
\text { assessment for curriculum designing. } \\
\text { - No opinions are taken from students } \\
\text { about learning strategies (teaching } \\
\text { time, duration, learning method). }\end{array}$ \\
\hline 3) & $\begin{array}{l}\text { Goals and } \\
\text { objectives }\end{array}$ & $\begin{array}{l}\text { Course document } \\
\text { (Practical } \\
\text { syllabus) }\end{array}$ & & $\begin{array}{l}\text { - Deficiencies were found with respect } \\
\text { to format, organization and contents. } \\
\text { - The layout, language and } \\
\text { organization of the course objectives } \\
\text { were inconsistent. } \\
\text { - Course goals were not explicitly } \\
\text { stated. } \\
\text { - The goals and objectives were not } \\
\text { matching with modern needs which } \\
\text { also reflected in the assessments, } \\
\text { instruments and procedures included } \\
\text { in the current syllabus. }\end{array}$ \\
\hline
\end{tabular}




\begin{tabular}{|c|c|c|c|c|}
\hline 4) & $\begin{array}{l}\text { Educational } \\
\text { strategies }\end{array}$ & $\begin{array}{l}\text { Course } \\
\text { documents, } \\
\text { student-faculty } \\
\text { interview data }\end{array}$ & & $\begin{array}{l}\text { - Strategies did not include clinical } \\
\text { problem solving based on the } \\
\text { biochemical tests, group learning } \\
\text { and discussions. } \\
\text { - No exposure of students to hospital } \\
\text { environment, hospital clinical } \\
\text { laboratories and patients. } \\
\text { - No elective strategy was used, all } \\
\text { students have same curriculum. } \\
\text { - No case presentation and case } \\
\text { discussion. }\end{array}$ \\
\hline 5) & Implementation & $\begin{array}{l}\text { Course } \\
\text { document, } \\
\text { Practical syllabus }\end{array}$ & $\begin{array}{l}\text { - Sufficient numbers of } \\
\text { hours are available to } \\
\text { deliver it in an optimal } \\
\text { way. } \\
\text { - Well established lab, } \\
\text { and dedicated faculty } \\
\text { members, } \\
\text { - Administrative } \\
\text { support is available. } \\
\text { - Seminars. } \\
\text { - Sufficient resources - } \\
\text { (faculty, } \\
\text { computing, secretarial } \\
\text { and other support } \\
\text { staff, patients) } \\
\text { - Facilities: (internet, } \\
\text { instruments } \\
\text { equipment, LCD, } \\
\text { projectors, seminar } \\
\text { hall etc to deliver the } \\
\text { curriculum. }\end{array}$ & $\begin{array}{l}\text { - No group learning sessions, } \\
\text { - Time distribution for practicals is not } \\
\text { correct. } \\
\text { - Active learning is not optimized. } \\
\text { - Lack of guidance and direction to } \\
\text { the teachers caused an inconsistent } \\
\text { understanding of the course's } \\
\text { objective. } \\
\text { - Approach to teaching does not uses } \\
\text { laboratory instruments and a clinical } \\
\text { presentation format. } \\
\text { - No strategies (pilot or inphase) to } \\
\text { implement the new ideas to improve } \\
\text { the curriculum. }\end{array}$ \\
\hline 6) & Evaluation & $\begin{array}{l}\text { Student practical } \\
\text { examination data, } \\
\text { Group discussion } \\
\text { from students and } \\
\text { faculty }\end{array}$ & & $\begin{array}{l}\text { - Lack of suitable methods to evaluate } \\
\text { clinical knowledge and skills of } \\
\text { students. } \\
\text { - No self-assessment procedure (Lack } \\
\text { of feedback to the faculty about their } \\
\text { performance as teachers). } \\
\text { - No feedback is taken from students } \\
\text { about the teachers, teaching } \\
\text { techniques etc. } \\
\text { - Objectives and students } \\
\text { examinations are not aligned. } \\
\text { - Lack of Objective Structured } \\
\text { Practical Examination (OSPE)) and } \\
\text { Objective Structured Assessment of } \\
\text { Technical Skills (OSATS). } \\
\text { - No structured checklists to increase } \\
\text { reliability and validity. } \\
\text { - No audit from university to check the } \\
\text { performances of students and } \\
\text { faculty. } \\
\text { - No formal meetings and group } \\
\text { discussion or teaching sessions to } \\
\text { revise, improve update and analyze } \\
\text { weaknesses of curriculum. }\end{array}$ \\
\hline
\end{tabular}




\section{2) Student's Perceptions}

Interviews with students showed that commitment, dedication and clinical experience of teaching faculty, good infrastructure and facilities were the major strengths of the curriculum. A number of weaknesses were also identified and summarized (Tables 2, 3).

Table 2: Perception of students about the undergraduate biochemistry laboratory curriculum

\begin{tabular}{|c|c|c|c|}
\hline Data source & Strengths & Weaknesses & Exemplar quotes \\
\hline Students interview & $\begin{array}{l}\text { - Dedicated faculty } \\
\text { members. } \\
\text { - Sufficient facilities and } \\
\text { laboratory set up in the } \\
\text { department. }\end{array}$ & $\begin{array}{l}\text { - Traditional manual } \\
\text { methods, } \\
\text { - No contact with the } \\
\text { hospital and patients } \\
\text { - No learning of applied } \\
\text { aspects of clinical } \\
\text { biochemistry, } \\
\text { - No demonstration } \\
\text { about the modern } \\
\text { instrument and } \\
\text { reagents handling. } \\
\text { - No case history pattern } \\
\text { to understand the } \\
\text { clinical scenario of the } \\
\text { diseased condition. }\end{array}$ & $\begin{array}{l}\text { - Our practical } \\
\text { curriculum seems to } \\
\text { stress upon the } \\
\text { traditional manual } \\
\text { method of metabolite } \\
\text { estimation. } \\
\text { - Practical sessions } \\
\text { should be more } \\
\text { interactive. } \\
\text { - Students should be } \\
\text { given example of } \\
\text { patients urine/blood } \\
\text { reports and asked to } \\
\text { discuss about the } \\
\text { probable diagnosis. }\end{array}$ \\
\hline
\end{tabular}

Table 3: Generation of Themes Form Student Based Interviews

\begin{tabular}{|c|l|l|}
\hline SR no & \multicolumn{1}{|c|}{ Themes } & \multicolumn{1}{|c|}{ Key points } \\
\hline 1 & $\begin{array}{l}\text { Very brief introduction to role of clinical } \\
\text { biochemistry laboratory in hospital settings. }\end{array}$ & $\begin{array}{l}\text { Ambiguity at the undergraduate level regarding } \\
\text { use of biological samples for identifying } \\
\text { abnormalities. Equipment commonly used for } \\
\text { analysis of biochemical parameters. }\end{array}$ \\
\hline 2 & $\begin{array}{l}\text { Inclusion of recent advances in diagnostic } \\
\text { methods and analytical instruments. }\end{array}$ & $\begin{array}{l}\text { No inclusion of new and advanced biomarkers. } \\
\text { No synchronization with the modern analytic } \\
\text { methods. }\end{array}$ \\
\hline 3 & $\begin{array}{l}\text { Clubbing of clinical case taking \& diagnostic } \\
\text { evaluation. }\end{array}$ & $\begin{array}{l}\text { Minimum teaching of clinical cases. } \\
\text { Less early clinical exposure }\end{array}$ \\
\hline
\end{tabular}

\section{3) Curriculum Modification}

After identification of the weaknesses of the present curriculum and triangulating data from all sources, an attempt was made to design a modified curriculum in which the objectives and content were structured and aligned with teaching learning methods and assessment strategies (Table 4). For the first time, measures for honing and assessing interpretative skills and problem solving skills of students were incorporated. The modified curriculum was also compared with the present curriculum at the University (Table 5).

Table 4: Alignments of objectives with teaching learning methods and assessment strategies

\begin{tabular}{|c|l|l|l|}
\hline $\begin{array}{c}\text { SR } \\
\text { No. }\end{array}$ & \multicolumn{1}{|c|}{ Learning objectives/outcomes } & \multicolumn{1}{|c|}{$\begin{array}{c}\text { Teaching and } \\
\text { learning activities }\end{array}$} & \multicolumn{1}{c|}{ Assessment } \\
\hline 1 & $\begin{array}{l}\text { At the end of practical class, students } \\
\text { shall be able to- } \\
- \text { Choose appropriate biochemical tests for } \\
\text { confirmation of diagnosis of the disease } \\
\text { condition. }\end{array}$ & $\begin{array}{l}\text { Preparation of cases } \\
\text { Group Discussion }\end{array}$ & $\begin{array}{l}\text { Short cases history to choose } \\
\text { relevant biochemical tests for } \\
\text { the diagnosis of diseases. } \\
\text { Discussion of the clinical } \\
\text { relevance of the analytes } \\
\text { estimated }\end{array}$ \\
\hline
\end{tabular}




\begin{tabular}{|c|c|c|c|}
\hline 2 & $\begin{array}{l}\text { Interpret laboratory results in patients in } \\
\text { order to make a laboratory diagnosis or } \\
\text { confirm a clinical diagnosis of disease. }\end{array}$ & $\begin{array}{l}\text { Demonstration } \\
\text { Small group sessions }\end{array}$ & $\begin{array}{l}\text {-Case histories with laboratory } \\
\text { results for interpretation of } \\
\text { laboratory results in patients } \\
\text { with specific disease condition. }\end{array}$ \\
\hline 3 & $\begin{array}{l}\text { Explain the principle of functioning of } \\
\text { diagnostic instruments and instruments } \\
\text { commonly used in a biochemistry laboratory } \\
\text { and their application. }\end{array}$ & $\begin{array}{l}\text { Hands on training and } \\
\text { tutorials }\end{array}$ & $\begin{array}{l}\text {-Spot and discussion on } \\
\text { laboratory instruments. } \\
\text { OSCE Station }\end{array}$ \\
\hline 4 & $\begin{array}{l}\text { Interpret electrophoretic patterns } \\
\text { associated with different disease conditions. }\end{array}$ & Demonstration & $\begin{array}{l}\text { - OSPE } \\
\text { observation, marking, checklist }\end{array}$ \\
\hline 5 & $\begin{array}{l}\text { Apply principles and knowledge of nutrition } \\
\text { to be able to advise patients on optimal diets } \\
\text { in health and disease }\end{array}$ & Tutorial & $\begin{array}{l}\text {-Applied aspects of nutrition } \\
\text { (spots and discussion). }\end{array}$ \\
\hline 6 & $\begin{array}{l}\text { Identify abnormal constituents of urine and } \\
\text { carrying out relevant tests and interpretation } \\
\text { and discussion of the results. }\end{array}$ & $\begin{array}{l}\text { Demonstration, tutorial } \\
\text { and practicals }\end{array}$ & $\begin{array}{l}\text {-Analysis of unknown specimen } \\
\text { of urine to detect abnormal } \\
\text { constituents of urine. } \\
\text {-Checklist }\end{array}$ \\
\hline
\end{tabular}

Table 5: Comparison of current and modified course objectives, content and practical assessments

\begin{tabular}{|c|c|c|c|}
\hline $\begin{array}{l}\text { Sr. } \\
\text { No. }\end{array}$ & & Current & Modified \\
\hline 1 & Objectives & $\begin{array}{l}\text { At the end of the course, the } \\
\text { students shall be able to - } \\
\text { 1) Make use of conventional } \\
\text { techniques/ instruments to perform } \\
\text { biochemical analysis relevant to } \\
\text { clinical screening and diagnosis. } \\
\text { 2) Analyse and interpret } \\
\text { investigative data. } \\
\text { 3) Demonstrate the skills of solving } \\
\text { scientific and clinical problems and } \\
\text { decision making. } \\
\text { 4) Suggest experiments to support } \\
\text { theoretical concepts and clinical } \\
\text { diagnosis. }\end{array}$ & $\begin{array}{l}\text { At the end of practical class, students shall be } \\
\text { able to- } \\
\text { 1) Choose appropriate biochemical tests for } \\
\text { confirmation of diagnosis of the disease } \\
\text { condition. } \\
\text { 2) Interpret laboratory results in patients in order } \\
\text { to make a laboratory diagnosis or confirm a } \\
\text { clinical diagnosis of disease. } \\
\text { 3) Explain the principle of functioning of } \\
\text { diagnostic instruments and instruments } \\
\text { commonly used in a biochemistry laboratory and } \\
\text { their application. } \\
\text { 4) Interpret electrophoretic patterns associated } \\
\text { with different disease conditions. } \\
\text { 5) Apply principles and knowledge of nutrition to } \\
\text { be able to advise patients on optimal diets in } \\
\text { health and disease. }\end{array}$ \\
\hline 2 & Assessments & $\begin{array}{l}\text {-Quantitative assessment of blood } \\
\text { sugar, urea and liver function test, } \\
\text { amylase, uric acid calcium and CSF } \\
\text { sugar. } \\
\text {-Qualitative or quantitative } \\
\text { estimation of biochemical } \\
\text { parameters. } \\
\text {-Normal and abnormal constituents } \\
\text { of urine. } \\
\text { Spot identification include- slide } \\
\text { identification tests of mono and } \\
\text { disaccharides, precipitation reaction } \\
\text { of urine, use of instruments, } \\
\text { identification of Hb derivatives, } \\
\text { GTT, electrophoretogram and } \\
\text { chromatogram. }\end{array}$ & $\begin{array}{l}\text {-Short case histories. } \\
\text {-Interpretation of laboratory results in patients } \\
\text { with specific disease condition. } \\
\text {-Identification of abnormal constituents of urine } \\
\text { and carrying out relevant tests and interpretation } \\
\text { and discussion of the results. } \\
\text {-Applied aspects of nutrition (spots and } \\
\text { discussion). } \\
\text {-Principles of important tests (including dipstick } \\
\text { tests) to detect abnormal constituents of urine. }\end{array}$ \\
\hline
\end{tabular}




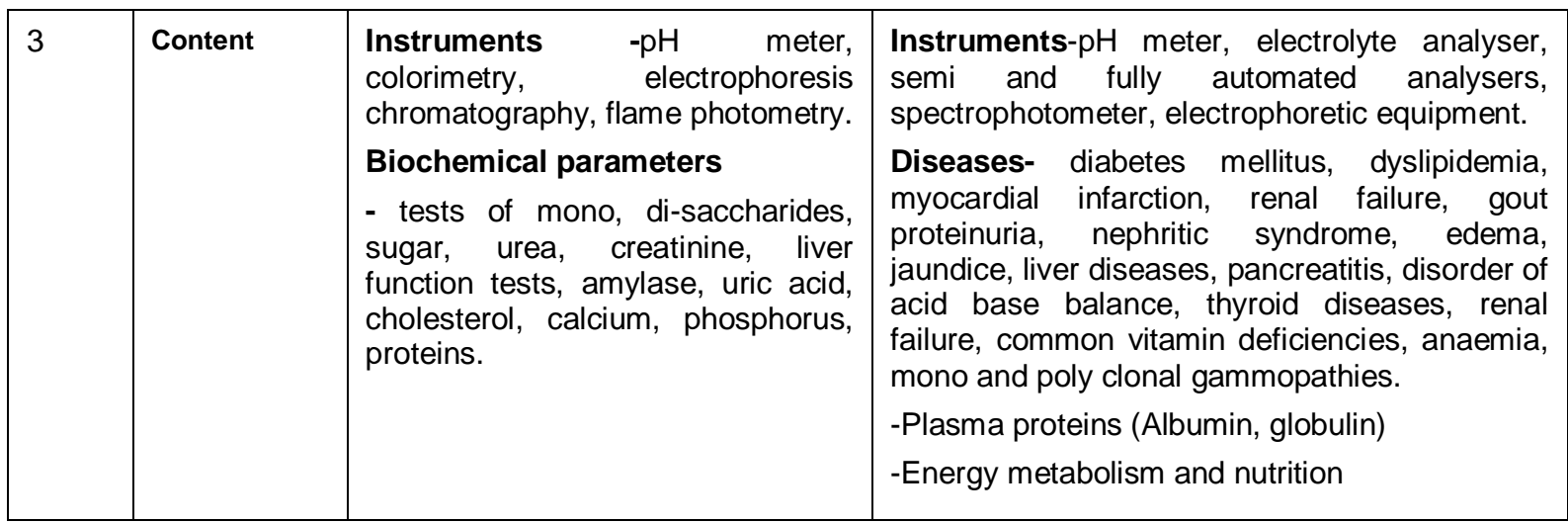

4) Evaluation of Pilot Implementation of checklist

In the training given to the faculty for pilot implementation of checklist, three levels of Kirkpatrick's evaluation were achieved:

a) Reaction-Reaction to use of the checklist was obtained from faculty by using feedback form. Significant satisfaction amongst the faculty was felt and their scoring skills and consistency was improved.

b) Learning-Learning was assessed by achieving the uniformity in marking among the faculty which was measured by comparing the student's scores with and without the use of the checklist.

As a result of comparison of marks, it was found that for the 49 subjects included in the study, the mean score on the marks allotted using checklist pattern $(M=9.18)$ was significantly lower $p<0.01 \quad(p=0.005)$ than the mean score on the marks without applying checklist pattern $(M=10.12)$ (Table 6). This was because the checklist evaluated the students on criteria like attitude reasoning and critical thinking other than theoretical knowledge.

Table 6: Evidence that marks allotment pattern for experiments given in the exam is valid

\begin{tabular}{|c|c|c|c|}
\hline $\begin{array}{c}\text { Marks without checklist pattern } \\
\text { (out of 15) (mean) } \mathbf{n = 4 9}\end{array}$ & $\begin{array}{c}\text { Marks with checklist pattern (out of } \\
\text { 15) (mean) } \mathbf{n}=\mathbf{4 9}\end{array}$ & $\mathbf{t}$-value & $\mathbf{p}$-value \\
\hline 10.12 & 9.18 & 2.922 & $<.005^{* *}$ \\
\hline
\end{tabular}

$\left({ }^{\star *}=\right.$ significant at the level of 0.01)

Table 7: Checklist for Urine Report Experiment

\begin{tabular}{lc}
\hline \multicolumn{1}{c}{ Particulars (Urine Report) } & Marks allotted \\
\hline Physical characteristics (writing + performing) & 1 \\
Specific gravity & 1 \\
Rest of the parameters such as colour, odour, etc. & 1 \\
Chemical constituents (writing +performing) & 1 \\
Proteins, Glucose & 1 \\
Blood & 1 \\
Bile salts and pigments & 1 \\
Ketone bodies & 2 \\
Clinical interpretation of the positive constituents & \\
(generally 2 positive constituents are kept) & 5 \\
Viva Voce & 1 \\
Report presentation format & 15 \\
Total & 1 \\
\hline
\end{tabular}


a) Reaction: Reaction to use of the checklist was obtained from faculty by using feedback form. Significant satisfaction amongst the faculty was felt and their scoring skills and consistency was improved.

b) Learning: Learning was assessed by achieving the uniformity in marking among the faculty which was measured by comparing the student's scores with and without the use of the checklist. As a result of comparison of marks, it was found that for the 49 subjects included in the study, the mean score on the marks allotted using checklist pattern $(M=9.18)$ was significantly lower $p<0.01 \quad(p=0.005)$ than the mean score on the marks without applying checklist pattern ( $M=10.12)$ (Table-6). This was because the checklist evaluated the students on criteria like attitude reasoning and critical thinking other than theoretical knowledge.

c) Behaviour: Faculty used the checklist for subsequent laboratory based assessments indicating change in behaviour while doing evaluation. Impact was noted when the faculty asked for the use of checklist even after the study was over.

\section{Discussion}

This study was designed to review current practices in biochemistry laboratory based curriculum and to seal the gaps between course objectives, content and assessments. Multitheory approach and detailed triangulation process for curriculum appraisal, evaluation, development and implementation were used. In concordance with the first objective the strengths and weaknesses of the current undergraduate biochemistry practical curriculum were evaluated using Kern's framework. Major weaknesses found were absence of formal need assessment, case presentation and discussion. The layout, language and organization of the course objectives were inconsistent. Also, no formal meetings, group discussions and selfassessment procedures could be identified. Thus the current curriculum lacked the basic and crucial elements essential for optimal learning.

As the second objective was to reform practical curriculum, it was renewed using Kern's framework and stakeholder's opinions. The changes made, it is hoped, shall help students to get early clinical exposure to develop problem-solving skills and self-direction to ensure that they have active responsibility for their learning process (West et al., 2000;
Dornan et al., 2006; Taylor \& Miflin, 2008). So, Kern's framework used in the study, served two purposes. It worked as a curriculum evaluation tool and at the same time it worked as a tool for curriculum modification.

Recreating a curriculum is intimately linked to the needs of learners and society-needs which periodically require re-examination thus emphasizing that need assessment is a critical step (Kern et al., 2010). This study acknowledged that this step was neglected in the present curriculum and further realized the significance of conducting an initial needs assessment in developing clear and meaningful objectives.

For a medical curriculum to be an effective means of learning for today's students, it must be written with knowledge of their priorities, needs and abilities. The way in which this can be best achieved is by the inclusion of current student's opinions in designing a new curriculum. It is by actively seeking student involvement and using their input, that faculties will be able to create a consumer-friendly curriculum (Huppatz, 1996).

As the student's views are indispensable to amend the curriculum their interviews were recorded (Table 4). Generated themes from the interviews were used to prepare new objectives and to modify the curriculum. The deficiencies in curriculum observed by the stakeholders (student-faculty) were identical to those found after Kern's evaluation and included absence of important learning objectives and discrepancies between objectives and content. Also, the objectives were not aligned to teaching learning methods and assessments. Moreover, there was no association between laboratory and clinical practices. Such a needs assessment was also documented in a study where guidelines for biochemistry curriculum alteration were recommended after considering the students views. Biochemical concepts and their clinical conditions were identified as critical steps toward enhancing relevance of clinical biochemistry (Wendelberger et al., 1998).

In our process of curriculum modification, laboratory based curriculum was designed to modify the way biochemistry is taught and assessed. New objectives, content and assessments were set keeping in mind the requirements of a doctor at the end of the undergraduate medical course (Table 5).

Wet and redundant experiments were removed and new experiments were designed to 
improve clinical and problem solving skills of the students in order to incorporate adequate skills for the execution of diagnostic tests, latest instrument handling was also added which was one of the themes developed after need assessment.

\section{Pilot Implementation of modified curriculum}

An organization's prior history with implementing innovation influences that organization's subsequent change efforts (Corbett et al., 1984). No previous history of biochemistry curriculum innovation and implementation could be observed in the institutes. This study is an initiative to innovate and implement curriculum and to encourage periodical innovation process.

In this project, we implemented the innovation as a pilot project because fully implementing curricular change in medical schools to incorporate innovations is a challenge as many factors such as leadership, funding, human resource development etc. affect the process (Altrichter, 2005; Bland et al., 2000). The chief objective of a pilot project is to test the draft curriculum in a small number of training situations and in the context in which the curriculum will be used. This helps to highlight to the curriculum developers whether the curriculum is understandable and relevant to the users and whether it works in practice. Based on these findings, the curriculum can be modified as appropriate to meet the needs of the potential students. Piloting can also assist to create the most appropriate course as often the paper curriculum does not work as expected in practice because of unforeseen situations or responses by students or teachers (McKimm, 2007).

Training was given to the faculty for using checklist of (urine experiment) practical evaluation. Three levels of Kirkpatrick's evaluation were achieved. It helped them to increase their scoring skills and to analyse and improve over all practical skills of students. Uniformity in marking was achieved by using the checklist and faculty used the checklist for subsequent practical assessments indicated change in behaviour. Evaluation of effectiveness of implemented programme are not given due importance as that of their planning and implementation (Rajeev et al., 2009). In this study not only the modified curriculum implemented as a pilot but its effectiveness was also measured using Kirkpatrick's model to assess the usefulness of the implemented programme.
Through this project, as a result of evidence based and collaborative process, a new practical curriculum structure has been developed. It is structured around generated themes from triangulation and designed considering the learning outcomes that describe the clinical competencies to be achieved after completing the practical course. Planning for redesigned biochemistry practical curriculum has been done, implementation has been initiated through our pilot study but institutionalization is still to be achieved.

\section{Conclusions}

Though there was a growing discontent amongst the faculty and students regarding the practical curriculum, no steps had been taken to alleviate this. Under these circumstances, it was thought that it would be wise to make small inroads by involving stakeholders in collecting data and distilling the strengths and weaknesses of the curriculum and to offer insights into the ways to modify it. This systematic appraisal will help to lend credibility for change to the curriculum. Therefore our study offers a snapshot of a review on traditional current undergraduate biochemistry practical curriculum of India. The data derived from this study has helped to make suggestions to the stakeholders and other decision making bodies in India.

\section{Authors' Contribution}

SD prepared the study design and carried out data collection and data analysis. SM contributed to the data analysis and writing of the manuscript. DM contributed to reviewing and editing of manuscript. All the authors have reviewed and approved the final version of the manuscript.

\section{Competing Interests}

The authors declare no competing interests.

\section{Acknowledgements}

The authors acknowledge Dr. Thomas Chacko, Director, Director, PSG-FAIMER South Asia Regional Institute, Coimbatore, for introducing Kern's evaluation of curriculum to SD. This research project was supported in part by the Foundation for Advancement of International Medical Education and Research (FAIMER). However, the findings and conclusions do not necessarily reflect the opinions of this organization. 


\section{References}

Altrichter, H. (2005) Curriculum implementation limiting and facilitating factors, In: Second University of York-IPN Conference on Science Education, Kiel, Germany.

Berk, R.A., (2006) Thirteen strategies to measure college teaching: a consumer's guide to rating scale construction, assessment, and decision making for faculty, administrators, and clinicians, Sterling, Va: Stylus Pub Llc.

Biggs, J. (2003) Aligning teaching and assessing to course objectives, Teaching and Learning in Higher Education: New Trends and Innovations, pp. 13-17.

Bland, C.J., Starnaman, S., Wersal, L., MooreheadRosenberg, L., Zonia, S. \& Henry, R. (2000) Curricular change in medical schools: how to succeed, Academic Medicine, 75, 6, pp.575-594.

Brodsky, D. \& Newman, L.R. (2011) Educational Perspectives: A Systematic Approach to Curriculum Development, Neoreviews, 12, 1, pp. e2-e7.

Corbett, H.D., Dawson, J., Firestone, W., (1984) School context and school change: Implications for effective planning, Columbia University: Teachers College Press.

Creswell, J.W., (2003) Research DesignQualitative, Quantitative, and Mixed Methods Approaches [2nd ed.] Thousand Oaks, CA: SAGE, pp. 246.

Dandekar, S.P., Maksane, S.N. \& McKinley, D., (2012) A Survey Validation and Analysis of Undergraduate Medical Biochemistry Practical Curriculum in Maharashtra, India, Indian Journal of Clinical Biochemistry, 27, 1, pp. 5260.

Dornan, T., Littlewood, S., Margolis, S.A., Scherpbier, A., Spencer, J. \& Ypinazar, J., (2006) How can experience in clinical and community settings contribute to early medical education? A BEME systematic review. Medical Teacher, 28, 1, pp. 3-18.

D'Souza, J.M., Raghavendra, U., D'Souza, D.H., D'Souza, N.D.R., (2013) Teaching Learning of Biochemistry in undergraduate medical curriculum: Perceptions and Opinions of Medical Students, Education in Medicine, 5, 2, pp. e46-53.

Epstein, R.M. \& Hundert, E.M. (2002) Defining and assessing professional competence, Journal of the American Medical Association, 287, pp. 226-235.
Huppatz, C. (1996) The essential role of the student in curriculum planning, Medical Education, 30, 1, 9-13.

Kern, D.E., Thomas, P.E., Hughes, M.D. [Eds.] (2010) Curriculum Development for Medical Education: A six-step approach, Baltimore: Johns Hopkins University Press.

Kirkpatrick, D.L. (1998) Evaluating training programs: the four levels [2 ${ }^{\text {nd }}$ Ed.] San Francisco, CA: Berrett-Koehler.

McKimm, J., (2007) Curriculum design and development, London: School of Medicine, Imperial College Centre for Educational Development.

Michael, L.G., (2001) Identifying, Appraising and Implementing Medical Education Curricula: A guide for Medical Educators, Annals of Internal Medicine, 135, 10, pp. 889-896.

Mishra, V., Kumar, S., Siwach, V., Sharma, N.K., Angral, R., Mujumdar, A. \& Sharma, A.K. (2000) Need for bringing in a change in biochemistry curriculum to make it clinically oriented? The Journal of the Associations Physicians of India, 48, 6, pp.635-638.

Peyton, J.W.R., (1998) Teaching and Learning in Medical Practice, Manticore Europe Ltd, Rickmansworth.

Rajeev, P., Madan, M. S., Jayarajan, K. (2009) Revisiting Kirkpatrick's model -an evaluation of an academic training course, Current Science 96, 2, pp. 272-276.

Rethy, K.C. \& Khoo, H.E., (2001) Curriculum design \& implementation:The basics, CTDL Brief, 4, 6 .

Taylor, D. \& Miflin, B. (2008) AMEE Guide 36: Problem-based learning: Where are we now? Medical Teacher, 30, 8, pp. 742-763.

Undergraduate biochemistry curriculum. [Available at: http://www.muhs.ac.in/upload/syllabus/ Phase1_060810_16082012_1233.pdf]

Virginia, B. \& Clarke, V. (2006) Using thematic analysis in psychology, Qualitative Research in Psychology, 3, 2, pp. 93.

Wendelberger, K.J., Burke, R., Haas, A.L., Harenwattananon, M. \& Simpson, D., (1998) Identifying Opportunities for Vertical Integration of Biochemistry and Clinical Medicine, Advances in Health Sciences Education, 3, 3, pp. 157-164.

West, D.C., Pomerory, J.R., Park, J.K., Gerstenberger, E.A. \& Sandoval, J.M., (2000) Critical thinking in graduate medical education: a role of concept mapping assessment? Journal of the American Medical Association, 284, pp. 1105-1110. 